\title{
Toxicity and Degradation of Explosives
}

\author{
Hans Stucki*
}

\begin{abstract}
Safety regulations about handling energetic materials deal mostly with the protection of man against explosions. Explosives contain many components with toxic hazards where protection measures are necessary or a replacement by other substances should be considered. Not only the well-known toxins like aromatic nitro compounds, nitrosamines, mercury, and lead are important, but also hazardous burning and detonation products and metabolites arising in the environment need serious control. Residues of organic nitro compounds and nitrates in the environment show, influenced by the microbiology, slow degradation reactions. Recently developed compounds have to be investigated to assess toxicity risks and possible endocrine effects.
\end{abstract}

Keywords: Degradation · Energetic materials · Environmental impact · Explosives · Toxicity

\section{Introduction}

Several explosives and the components in explosive mixtures show toxic effects and are impacting the environment. We can find acute toxicity, chronic infection, and the risk for cancer when there is contact with the products over a prolonged period. In the environment, some explosives and their burning residues can be persistent for very long times, others slowly decompose.

These are the reasons why the workers in the explosives industry and people in contact with such materials have to take care when manufacturing, handling, or using these products. The problems of the residues in the environment and the possible risks for man, animals and nature have to be clarified seriously.

${ }^{\star}$ Correspondence: Dr. H. Stucki

armasuisse

Science and Technology

Feuerwerkerstrasse 39

$\mathrm{CH}-3602$ Thun

Tel.: +41332282944

Fax: +41332284601

E-Mail: hans.stucki@armasuisse.ch

\section{Toxic Aspects in Manufacturing}

First of all, the safety procedures of the chemical industry have to be observed when manufacturing explosive substances. In addition, the regulations dealing with the safety and the protection of the workers against possible explosions have to be followed.

\subsection{Toxicity of Glycerol Trinitrate (Nitroglycerine)}

Glycerol trinitrate (nitroglycerine) is used in medicine as a vasodilator. In case of an attack of angina pectoris a nitroglycerine capsule is placed under the tongue. This helps dilate blood vessels and more blood can reach the heart.

Nevertheless human beings have to be protected against chronic exposure to nitroglycerine. This substance is usually absorbed through the skin and by inhalation. Nitroglycerine can produce methaemoglobinaemia and the body develops a tolerance to this substance. Withdrawal from frequent exposure to nitroglycerine may cause severe headaches.

\subsection{TNT and Other Aromatic Nitro Compounds}

The toxicity of aromatic nitro compounds is of great importance because of their wide distribution in munitions: $2,4,6$ trinitrotoluene (TNT) is present in bombs and shells and dinitrotoluene (DNT) is used as an energetic additive in propellants. Not only contact with the original substances but also the natural impurities and the decomposition products has to be controlled since these represent compounds with higher toxic potentials. In the carcinogen list of the US National Institute of Occupational
Safety and Health (NIOSH) the DNTs are noted; TNT presents a lesser cancer risk and is not on the list [1]. The DNTs normally are more toxic for mammals than TNT, but TNT is a stronger toxin for fishes. Table 1 shows some toxic and carcinogenic data of TNT and DNTs.

The toxic effects of TNT include blood changes, cyanosis, methaemoglobinaemia and toxic hepatitis. Contamination is possible by inhalation, ingestion and skin absorption. Vaporization of melted TNT and dust at the workplace have to be avoided. The other organic high explosives like cyclotrimethylenetrinitramine (RDX), cyclotetramethylenetetranitramine (HMX), and pentaerythritol tetranitrate (PETN) have lower vapor pressures and the toxic effects are of less importance.

\subsection{Mercury Fulminate}

The primary explosive mercury fulminate was the product mainly used in earlier times for percussion caps and as a detonator. In Swiss munitions production it was replaced by lead compounds and other products between 1950 and 1960, because many workers in the production plants showed health problems connected with mercury. In modern explosives the mercury is no longer a problem.

Low level poisoning with mercury leads to fatigue, headaches, lack of concentration, hair loss until ultimately the central nervous system is attacked and brain and liver are damaged.

\subsection{Diphenylamine and Nitrosamines}

Diphenylamine (DPA) is often used as a stabilizer in nitrocellulose propellants. Af- 
Table 1. Toxicity and carcinogenic data of TNT and DNTs

\begin{tabular}{|c|c|c|c|}
\hline Property & $\begin{array}{l}\text { 2,4,6-trinitro } \\
\text { toluene (TNT) }\end{array}$ & $\begin{array}{l}2,4 \text {-dinitro } \\
\text { toluene }\end{array}$ & $\begin{array}{l}\text { 2,6-dinitro } \\
\text { toluene }\end{array}$ \\
\hline $\begin{array}{l}\mathrm{LD}_{50} \text { for rat } \\
\text { lethal dose, } 50 \% \text { kill }\end{array}$ & $800-1300 \mathrm{mg} / \mathrm{kg}$ & $268-650 \mathrm{mg} / \mathrm{kg}$ & $177-795 \mathrm{mg} / \mathrm{kg}$ \\
\hline $\begin{array}{l}\mathrm{LC}_{50} \text { for fish } \\
\text { lethal concentration, } 50 \% \text { kill }\end{array}$ & $2.4 \mathrm{mg} / \mathrm{l}$ & $35.5 \mathrm{mg} / \mathrm{l}$ & 19.8 mg/l \\
\hline Carcinogenic class (D) & $\begin{array}{l}\text { possible } \\
\text { carcinogen (B2) }\end{array}$ & $\begin{array}{l}\text { possible } \\
\text { carcinogen (B2) }\end{array}$ & $\begin{array}{l}\text { unambiguous } \\
\text { carcinogen (B1) }\end{array}$ \\
\hline $\begin{array}{l}\text { TDI = Tolerable Daily } \\
\text { Intake per kg weight (D) }\end{array}$ & $0.05 \mu \mathrm{g}$ & $0.2 \mu \mathrm{g}$ & $0.0002 \mu \mathrm{g}$ \\
\hline $\begin{array}{l}\text { Equivalent factor for long-term } \\
\text { exposure }(T N T=1)(D)\end{array}$ & 1 & 5 & 150 \\
\hline $\begin{array}{l}\text { Permissible Exposure Limit } \\
\left(\mathrm{mg} / \mathrm{m}^{3} \text { in air) US-OSHA }\right.\end{array}$ & 1.5 & 1.5 & 1.5 \\
\hline
\end{tabular}

ter long storage N-nitroso-DPA is detected, formed by the decomposition products of the nitrocellulose and the DPA. The nitrosamines have been described as a widely acting and potent group of carcinogens and the US Occupational Safety and Health Administration (OSHA) has classified these chemicals as carcinogens [1]. They decompose and have an effect on the DNA in organisms. The aromatic nitroso compounds seem to be less dangerous as a cancer risk than the aliphatic compounds. Nevertheless, persons handling such products must be seriously protected against any contact [2].

There are new efforts in the industry to eliminate the DPA as a stabilizer in the field of the explosives. One substitute which is discussed, is triphenylamine in which formation of $\mathrm{N}$-nitroso compounds is not possible.

\section{Toxicity Problems in the Use of Explosives}

\subsection{Perchloronaphthalene Smoke}

In 1940 the Swiss army introduced a new smoke-generating composition, con-

Table 2. Components of the hazardous perchloronaphthalene smoke mixture used in 1940 in Switzerland

\begin{tabular}{lc|} 
Component & Percentage [\%] \\
\hline Perchloronaphthalene & 38 \\
Zn and ZnO & 25 \\
Calcium silicide & 6 \\
Ammonium perchlorate & 15 \\
Ammonium chloride & 15
\end{tabular}

taining perchloronaphthalene as organic chlorine compound. The complete formulation is listed in Table 2. The first small scale use and burning of this mixture for the camouflage of military objects showed good results. On alpine pastureland in the central parts of Switzerland, large quantities of this product were burned off. After the tests cows and other animals fell sick in these regions. 15'000 cows were involved in this environmental disaster - an 'alpine Seveso'.

The perchloronaphthalene used in 1940 was of technical grade with a chlorine content of $62-64 \%$, corresponding to a hexachloronaphthalene. Other impurities in this product are unknown. The mechanism of the formation of the highly toxic products has not been investigated and the compounds could not be analyzed at that time, but we can assume that the low burning temperature facilitated the formation of chloro dioxins, similar to the toxins of Seveso.

\subsection{Current Smoke Compositions}

At the present time, the most commonly used main compounds in smoke producing mixtures are red phosphorous, zinc compounds and PVC powders. Hexachloroethane $(\mathrm{HC})$ as a further organic chlorine compound is used in mixtures abroad. These HC mixtures are able to produce hexachlorobenzene in yields of approximately $0.5 \%$ [3]. Practically all organic chlorine compounds produce traces of chloro dioxins, when burning occurs at low temperatures.

Another problem when burning off red phosphorous is the formation and condensation of small quantities of toxic white phosphorous, a risk for animals and man. Zinc as a current component in the smokes is slightly toxic and impacts the immediate and extended environment of the site of combustion.

\subsection{Lead Dust in Indoor Shooting Ranges}

The layout of ventilation systems in closed shooting ranges is normally calculated to remove the carbon monoxide resulting from the incomplete burning of the propellants. Measuring the actual toxins in the air often shows that lead dust exceeds the limits. The decomposition of lead styphnate and other lead compounds in the percussion caps is responsible for the high lead emissions. Intensive shooting with pistols can result in a lead concentration in the air of more than $1 \mathrm{mg} / \mathrm{m}^{3}$. Most countries limit the long-term occupational exposure to $0.1 \mathrm{mg} / \mathrm{m}^{3}$.

This is the reason why lead-free primary mixtures like SINTOX ${ }^{\circledR}$ exist today and ammunition for pistols without lead in the percussion caps is available. Another source for lead dust is the bullet. The surface of the bullet must be protected, so that lead cannot be eroded in the gun. The complete replacement of lead in the bullet adversely influences the precision in shooting and leads to technical problems.

\section{Environmental Impact by Explosives}

\subsection{Mercury Residues at Old Shooting Ranges}

Analysis of the mercury content of the soil of old gun shooting ranges shows concentrations of 2-8 ppm of mercury at the locations where the guns were placed [4]. This contamination is restricted to the surface and to a layer of $20-40 \mathrm{~cm}$ in depth and covers an area of few square meters. The limits for mercury contamination of the soil, for instance in Switzerland at $0.5 \mathrm{ppm}$, are clearly exceeded. The contamination is the result of the use of mercury fulminate before 1960 and it remains for a very long time.

At old munitions demolition sites in the alpine regions, where the disposal of munitions and explosives was carried out by open burning and open detonation in the years before 1995 , the mercury concentrations of the soil reaches barely the limits, but the contaminated areas cover a surface with a diameter of some hundred meters [3].

\subsection{Organic Explosives in the Environment}

In some areas of military firing ranges and in the central areas of former munitions demolition grounds we can find residues of various explosives in the soil. One source is incomplete detonation or deflagration, which leads to fine or coarse explosive par- 
Table 3. Environmental behavior of explosives

\begin{tabular}{lllll} 
Explosive & $\begin{array}{l}\text { Solubility in water } \\
{\left[\mathrm{mg} / \mathrm{l}, 20^{\circ} \mathrm{C}\right]}\end{array}$ & $\begin{array}{l}\text { Distribution: } \\
\text { water/organic } \\
\text { carbon log Koc }\end{array}$ & $\begin{array}{l}\text { Adsorbance at } \\
\text { silicate, } \mathrm{K}_{\mathrm{d}}[\mathrm{l} / \mathrm{kg}]\end{array}$ & $\begin{array}{l}\text { Volatility, Hc } \\
\text { (Henry const.) } \\
{\left[\text { [atm } \mathrm{m}^{3} \mathrm{~mole}^{-1}\right]}\end{array}$ \\
\hline TNT & 130 & 3.2 & $21^{\prime} 500$ & $1.110^{-8}$ \\
PETN & $43\left(25^{\circ} \mathrm{C}\right)$ & 3.4 & - & $1.0710^{-9}$ \\
RDX & 70 & $0.9-2.4$ & 1.2 & $1.9610^{-11}$ \\
Tetryl & 75 & $1.7-3.5$ & 5.8 & $2.7910^{-11}$ \\
2-ADNT & 2800 & 0.4 & 2 '900 & - \\
4-ADNT & poorly soluble & 1.0 & 125 & -
\end{tabular}

ticles in the surroundings. Another source of explosives are unexploded shells, which penetrated into the ground without detonating. Such unexploded shells are hard to detect and to dispose of.

Dumping waste ammunition in the sea was common in many countries. Swiss military used lakes for the disposal of waste materials. This activity was discontinued in 1964 because of the introduction of a new law concerning the protection of water. In Switzerland, Lake Thun is the most affected lake with an estimated amount of 3'000 tons of deposited ammunition. The amount of TNT, as the main organic explosive, is estimated to be 500 tons. The degradation of the material and the liberation of chemical substances are expected to be very slow [7]. An analysis of the water of Lake Thun was carried out, TNT and its metabolites could not be found within detection limits of 1-20 ng/1 [5].

The situation is different at mining sites and tunnel construction sites where civil ex- plosives are used. The products used here are mixtures of inorganic nitrates and chlorates with mineral oils, paraffins and emulgators as additives. The water solubility of some components is high and explosives residues impact the environment faster and will degrade in shorter time.

\section{Degradation of Explosives in the Environment}

\subsection{Behavior of Explosives}

Military organic explosives normally have a low solubility in water. The decomposition of such materials needs a long time. TNT decomposition yields amino compounds, which is why the two most commonly found compounds, 2 -amino 4,6DNT (2-ADNT) and 4-amino 2,6-DNT (4ADNT) are included in the considerations. The environmental behavior, listed in several papers [6-8] is partly described in Table 3. Tetryl is the abbreviation of $\mathrm{N}$ -
methyl-N,2,4,6,-tetranitroaniline.

The concentrations of dissolved materials, caused by the low solubilities and absorbance effects, never can reach dangerous levels in the soil and in water, if we discount the sites with mines, unexploded shells, and large pieces of unburnt or unexploded explosives. The original state of these lost objects after a period of 30-40 years in the soil or in the water is still visible. It seems that not only the low solubility of these materials is responsible for the low concentrations found. The metal covers, the added wax and polymers, and the large crystals of the cast TNT all seem to delay the speed of dissolution.

\subsection{Degradation of TNT}

All organic explosives and their residues show degradation in the water and in the soil, influenced by microorganisms, light, oxygen and reducing chemicals. Many investigations regarding the decomposition of TNT molecules in the environment were executed and many degradation products are known [7-10]. Another source for the knowledge about the explosives and the formation of metabolites in the environment is the large amount of analytical data of soil and water samples, generated by the control analyses of sites with dangerous waste residues or polluted by explosives [11].

Scheme 1 presents the postulated scheme for TNT degradation under aerobic conditions like in the water of a clear lake. In Lake Thun and in the uppermost layers of the sediments at the bottom of this lake the oxygen content of the water is dominant and the degradation seems to be aerobic. Degradation begins with the formation of hydroxylamino compounds, which then

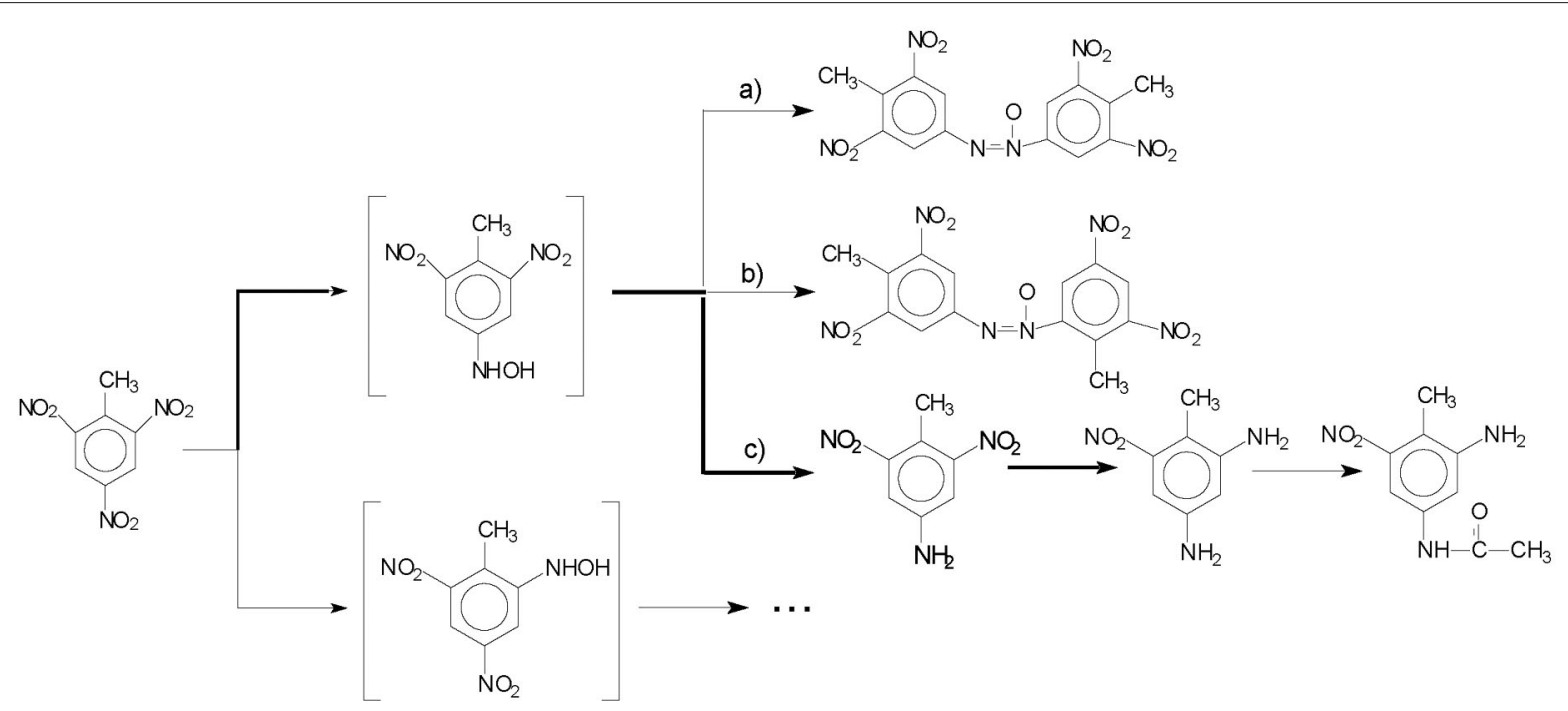

Scheme 1. Biological degradation of TNT in water under aerobic conditions [8][9]. a) and b) with high TNT concentrations, c) low TNT concentrations and corresponds to the situation in Lake Thun. A thick line indicates the main path. The most important end product is expected to be 2,4-diamino-6nitro-toluene. 


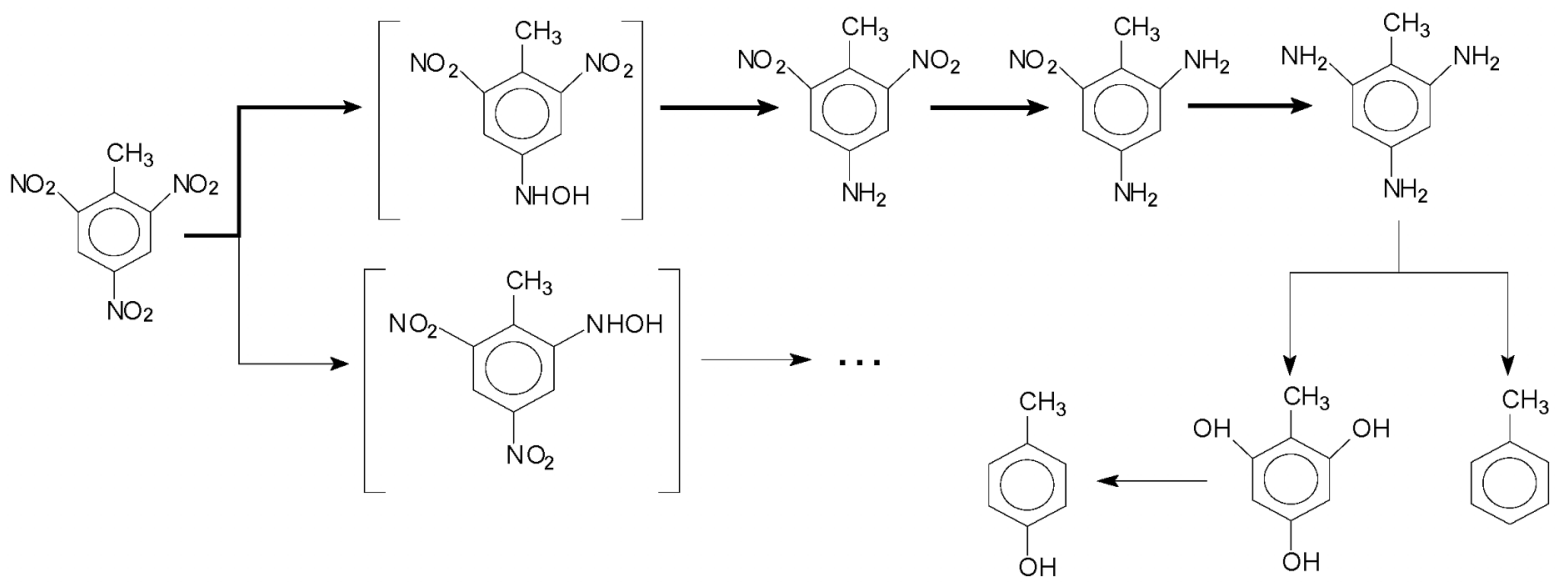

Scheme 2. Biological degradation of TNT in water under anaerobic conditions [8][10]. A thick line indicates the main path. The most important temporary products are expected to be mono-, di- and triamino toluene.

form partial or complete amino compounds. These are stable for a limited time only; afterwards complete mineralization takes place.

Anaerobic conditions are dominant in a soil containing a high level of organic compounds, or in the deeper parts of sediments at the bottom of lakes and also when soil with contamination of explosives is remediated by composting methods. The anaerobic situation is showed in Scheme 2. This degradation seems to be similar for observing stable intermediate amines and for a judgment of the toxic risks.

The reaction can start only when the substances are in a fine distribution in the soil or dissolved in water. The first step of TNT degradation is the reduction of a nitro group to a hydroxylamino group. The influence of oxygen leads to the production of intermediate azoxy compounds, followed by the formation of amines. The resulting products with a certain stability can be analyzed. They are mono-, di-, and tri-amino nitrotoluenes, formed in both cases, with and without the influence of oxygen.

The following degradation period, with the loss of nitrogen, formation of phenols, and then complete decomposition and mineralization, leading to $\mathrm{CO}_{2}$ and $\mathrm{H}_{2} \mathrm{O}$, is less explored.

\subsection{Toxic and Endocrine Risks}

Experiments of TNT with monkey, mouse and rat showed paternal effects on the testes, epididymis, sperm duct [12], but only with relatively high quantities of the explosive applied. The organic explosives contaminating the environment show mostly no toxic effects, because of the low solubility, the low tendency of enrichment in biological cycles and degradation in nature. Recently many chemicals impacting the environment are under discussion because they may have endocrine effects on wildlife and man.

A report of the European Community [13], listing 147 candidates, includes the compound 4-nitro toluene as a compound suspected to be potentially hormone-active. Additionally a WWF publication, dealing with the risks of artificial musk fragrances [14] names the two aromatic nitro compounds musk xylene and musk ketone, which are used as low-cost artificial musk fragrances, as endocrine-disrupting chemicals.

The widely used explosives and their degradation products need special examination concerning effects as endocrine disruptors. In a first investigation a mixture containing TNT, 2,6-DNT, 2,6-diamino-4nitrotoluene, 2,4-diamino-6-nitrotoluene, PETN, RDX and other energetic compounds was checked for hormone activity. The two employed test methods were: a yeast oestrogen screen (Routledge and Sumpter) [15] and a yeast androgen screen (Purvis et al.) [16]. In these two assays not only the estrogenic and androgenic activity of the explosives, but also the anti-estrogenic and anti-androgenic activities were investigated. In none of these tests was an endocrine disrupting potential of the explosives found [17]. This is a first indication that the examined explosives do not act as endocrine disruptors via estrogen - or androgen receptors. Nevertheless we have to complete analysis of the range of explosive compounds and metabolites and testing will continue in the near future.

\section{Disposal of Organic Explosives}

\subsection{Remediation of Contaminated Soil}

Soil and groundwater contamination by TNT has resulted from TNT production and munitions manufacturing. These residues come from the disposal of explosive wastes and from acid used in the nitration process. More than 50 years after contamination ended, TNT, its by-products and degradation products are detectable in the soil and in the water [11]. Methods for a clean up of such soils are washing, thermal treatment or removal. Another method of decontamination, tested in the lab and in pilot plants, is composting. The soil, containing low concentrations of explosives, is mixed with organic materials like hay, grass, leaves, horse manure, and garden soil. At reaction temperatures of $60-80{ }^{\circ} \mathrm{C}$, the explosives TNT, RDX and HMX present in concentrations of $1 \%$, disappeared completely within 10 weeks [18][19]. This degradation occurs only when the explosives are finely distributed; the problem of mines, unexploded shells and large pieces of unexploded or unburnt explosives in the ground cannot be solved by this method.

\subsection{Thermal Destruction Plants}

In the period of 1990 to 2000 various incineration plants for an ecological disposal of energetic waste materials were constructed. The disposal of ammunition and explosives can be carried out with legal compliance in such plants. At the same time, the NATO states, Switzerland and other nations did not allow destruction or disposal of these materials by open burning and open detonation.

The most important part of an incineration plant is a rotary kiln incinerator with a thick-walled steel tube or an other robust oven. After that follows a high-temperature secondary combustor. The gas stream is then cooled, washed and filtered; additionally a $\mathrm{NO}_{\mathrm{x}}$ removal tower is needed and mercurycontaining materials require carbon black filters. The preparation of the explosive ma- 
terial, the subdivision into small parts is expensive. Dangerous rockets and hazardous munitions are often cut in parts with the required size by abrasive water jet equipment.

\section{Acknowledgments}

The author thanks all who have contributed to this work. Special thanks to Mrs. Sonia Rodriguez Bares, Eidg. Forschungsanstalt Wädenswil, for literature search, analytical work and drawing the schemes, Mrs. Nina Schweigert, EAWAG Dübendorf, for testing the hormone activity of explosives, Peter Mäder and Beat Berger for review of the paper and Hansruedi Bircher for supporting this project.

Received: March 30, 2004

[1] 'Carcinogen List', National Institute for Occupational Safety and Health, NIOSH, http://www.cdc.gov/niosh/npotocca.html, update 2002.

[2] Houben-Weyl, 'Methoden der organischen Chemie', Bd. E 16a / Teil 2, 1990.

[3] H. Stucki, 'Environmental Contamination of Explosive Ordnance Disposal', 12th IRSAG Conference, MOD Abbey Wood, Bristol, UK, 2000.

[4] 'Schadstoffbelastung des Bodens bei Schiessanlagen', Kant. Amt für Umweltschutz Solothurn, $\mathrm{CH}$, Bericht Jan. 1994.

[5] S. Rodriguez Bares, H.R. Buser, T. Poiger, M.D. Müller, H.P. Kohler, 'Gewässerbelastung durch Sprengstoffe im Thunersee',
Report of Eidg. Forschungsanstalt Wädenswil, $\mathrm{CH}, 2003$.

[6] R. Haas, 'Stoffdatenblätter wichtiger Explosivstoffe', Auszug aus UBA-Texten 26/96, Umweltbundesamt, Berlin, D, 1996.

[7] H. Stucki, 'Die Munitionsmaterialien in den Thunersee-Deponien und ihr toxisches und endokrines Potential', Gruppe Rüstung FS 261, Thun, CH, Report Nr. 1723, 2003.

[8] S. Rodriguez Bares, T. Poiger, M.D Müller, H.P. Kohler, 'Gewässerbelastung durch Sprengstoffe im Thunersee', Report of Eidg. Forschungsanstalt, Wädenswil, $\mathrm{CH}, 2003$.

[9] S. McFarlan, '2,4,6-Trinitrotoluene Graphical Pathway Map', The University of Minnesota Biocatalysis/Biodegradation Database, http://umbbd.ahc.umn.edu/, 2002.

[10] S. McFarlan, G. Yao, 'Anaerobic Trinitrotoluene Pathway Map', The University of Minnesota Biocatalysis/Biodegradation Database, http://umbbd.ahc.umn.edu/, 2002.

[11] H. Holland, 'Erfahrungen aus der Bestimmung von sprengstoffspezifischen Schadstoffen in Boden- und Wasserproben', CPM-Seminar: Bewertung von sprengstoffspezifischen Schadstoffen auf Rüstungs- und militärischen Standorten, Bonn, D, 1994.

[12] '2,4,6-Trinitrotoluene, The Registry of Toxic Effects of Chemical Substances', NIOSH (US), update 2002.

[13] European Commission DG ENV, 'Towards the establishment of a priority list of sub- stances for further evaluation of their role in endocrine disruption', Final report 2000.

[14] 'Synthetic Musk Fragrances', WWF Publication, 2000.

[15] E.J. Routledge, J.P. Sumpter, 'Estrogenic Activity of Surfactants and Some of Their Degradation Products Assessed Using a Recombinant Yeast Screen', Environ. Toxicol. Chem. 1996, 15(3), 241-248.

[16] I.J. Purvis, D. Chotai, C.W. Dykes, D.B. Lubahn, F.S. French, E.M. Wilson, A.N. Hobden, 'Androgen-Inducible Expression System for Saccharomyces cerevisiae', Gene 1991, 106(1), 35-42.

[17] N. Schweigert, 'Oekotoxikologische Untersuchung der Sprengstoff-Proben Thunersee', Report of Swiss Federal Institute for Environmental Science and Technology (EAWAG), Dübendorf, $\mathrm{CH}$, Dec. 2003.

[18] D.L. Kaplan, A.M. Kaplan, 'Thermophilic biotransformation of 2,4,6-trinitrotoluene under simulated composting conditions', Appl. Environ. Microbiol. 1982, 44, 757-760.

[19] K.A. Feller, 'Biologischer Abbau von Trinitrotoluol', Proc. 23rd Intern. Ann. Conf. of ICT, Karlsruhe, D, 1992, pp 33-1-11. 